\title{
Perioperative care in elderly cardiac surgery patients
}

\author{
Ewa Kucewicz-Czech ${ }^{1}$, Katarzyna Kiecak², Ewa Urbańska², Tomasz Maciejewski², Robert Kaliś², \\ Waldemar Pakosiewicz ${ }^{2}$, Tadeusz Kołodziej ${ }^{3}$, Piotr Knapik ${ }^{2}$, Roman Przybylski ${ }^{4}$, Marian Zembala ${ }^{4}$ \\ ${ }^{1}$ Department of Anesthesiology and Intensive Care, Medical University of Silesia, Katowice, Poland \\ ${ }^{2}$ Department of Cardiac Anesthesiology and Intensive Care, SMDZ in Zabrze, Medical University of Silesia \\ in Katowice, Silesian Centre for Heart Diseases, Zabrze, Poland \\ ${ }^{3}$ Department of Anesthesiology and Intensive Care with Cardiac Monitoring, Upper Silesian Medical Centre, Katowice, Poland \\ ${ }^{4}$ Department of Cardiac, Vascular, and Endovascular Surgery and Transplantology, SMDZ in Zabrze, Medical University of Silesia \\ in Katowice, Silesian Centre for Heart Diseases, Zabrze, Poland
}

Kardiochirurgia i Torakochirurgia Polska 2016; 13 (4): 340-346

\begin{abstract}
Introduction: Surgery is an extreme physiological stress for the elderly. Aging is inevitably associated with irreversible and progressive cellular degeneration. Patients above 75 years of age are characterized by impaired responses to operative stress and a very narrow safety margin.

Aim: To evaluate perioperative complications in patients aged $\geq 75$ years who underwent cardiac surgery in comparison to outcomes in younger patients.

Material and methods: The study was conducted at the Silesian Centre for Heart Diseases in Zabrze in 2009-2014 after a standard of perioperative care in seniors was implemented to reduce complications, in particular to decrease the duration of mechanical ventilation and reduce postoperative delirium. The study group included 1446 patients.

Results: The mean duration of mechanical ventilation was $13.8 \mathrm{~h}$ in patients aged $\geq 75$ years and did not differ significantly compared to younger patients. In-hospital mortality among seniors was $3.8 \%$, a value significantly higher than that observed among patients younger than 75 years of age. Patients aged $\geq 75$ years undergoing cardiac surgery have significantly more concomitant conditions involving other organs, which affects treatment outcomes (duration of hospital stay, mortality).

Conclusions: The implementation of a standard of perioperative care in this age group reduced the duration of mechanical ventilation and lowered the rate of postoperative delirium.

Key words: cardiac surgery, elderly, mechanical ventilation, delirium.
\end{abstract}

\section{Streszczenie}

Wstęp: Operacja jest ekstremalnym urazem dla fizjologii zaawansowanego wiekiem organizmu. Starzenie nierozerwalnie wiąże się z nieodwracalną i postępującą degeneracją komórek. U pacjentów powyżej 75. roku życia obserwuje się upośledzenie reakcji na uraz operacyjny i bardzo wąski margines bezpieczeństwa.

Cel: Analiza powikłań w okresie okołooperacyjnym w grupie seniorów poddawanych zabiegom kardiochirurgicznym i porównanie ich z wynikami uzyskanymi w grupie pacjentów młodszych. Materiał i metody: Badanie przeprowadzono w Klinice Kardiochirurgii Śląskiego Centrum Chorób Serca w Zabrzu od momentu wprowadzenia standardu opieki okołooperacyjnej w tej grupie wiekowej (październik 2009 roku) do października 2014 roku. Analiza wyników objęła lata, w których stosowano standard znieczulenia i postępowania okołooperacyjnego u chorych powyżej 75. roku życia w celu ograniczenia powikłań, ze szczególnym uwzględnieniem skrócenia czasu wentylacji mechanicznej płuc i ograniczenia występowania zespołów majaczeniowych. Badana grupa liczyła 1446 pacjentów.

Wyniki: Wentylacja mechaniczna płuc u seniorów trwała średnio 13,8 godziny i jej czas nie różnit się od czasu wentylacji u młodszych pacjentów. Śmiertelność wewnątrzszpitalna u starszych chorych wyniosła 3,8\% i była istotnie wyższa niż u chorych poniżej 75. roku życia. Chorzy w wieku 75 lat i więcej kwalifikowani do operacji kardiochirurgicznych są znamiennie statystycznie częściej obciążeni schorzeniami dotyczącymi innych narządów, co wpływa na końcowy wynik leczenia (czas pobytu w szpitalu, śmiertelność).

Wnioski: Wprowadzenie standardu opieki okołooperacyjnej w tej grupie wiekowej spowodowało skrócenie czasu wentylacji mechanicznej płuc i zmniejszyło częstość występowania zespołów majaczeniowych.

Słowa kluczowe: kardiochirurgia, seniorzy, wentylacja mechaniczna, majaczenie.

Address for correspondence: Prof. Ewa Kucewicz-Czech, Department of Anesthesiology and Intensive Care, Medical University of Silesia, 45/47 Ziołowa St, 40-635 Katowice, Poland, phone/fax: +48 3235985 94, e-mail: kucewiczewa@op.pl

Received: 23.08.2016, accepted: 14.10.2016. 


\section{Introduction}

Chronological and biological age differ significantly from each other. Chronological age is the parameter used in clinical practice. It has been widely accepted to divide the elderly subjects into four age categories: young-old age (65-74 years), middle-old age (75-84 years), oldestold age ( $\geq 85$ years), and longevity ( $\geq 90$ years). No age is a contraindication for surgery if the clinical aim is not only to prolong life. The most important motivation for treatment is the preservation or improvement of the quality of life.

The philosophy of surgical treatment in seniors focuses on the rapid restoration of all physiological functions immediately after the procedure, which reduces the complication rates and the duration of hospital stay [1]

The occurrence of postoperative complications leads to a cascade of events resulting in disability, dependence, reduced quality of life, increased mortality, and a dramatic increase in treatment costs [2].

Seniors are characterized by different physiology, which justifies the individualization of the treatment process. One typical feature is reduced - hepatic perfusion, which leads to impaired drug metabolism. Furthermore, the number of drug-binding receptors is reduced, and the response to medications is thus delayed. Renal dysfunction extends the duration of drug elimination. Due to low albumin levels, the free drug fraction is increased, resulting in increased drug transport to the central nervous system (CNS). The volume of distribution is reduced due to the reduction of circulating blood volume by $20 \%$, which is associated with higher drug levels. Seniors are also more susceptible to medications as a result of increased concentrations of water-soluble drugs (due to lower water content) and reduced concentrations of fat-soluble drugs (due to increased sequestration of anesthetics in the adipose tissue and later their extended release) [3]. Diastolic dysfunction is a typical feature of the aging heart [4]

The effect of general anesthesia on the brain is an increasingly debated issue. The hypothesis that general anesthesia contributes to the progression of neurodegeneration has not been confirmed. However, some studies indicate that excessively deep anesthesia may affect the rate of cognitive dysfunction and postoperative delirium. In addition, increasing evidence suggests that cognitive dysfunction is aggravated by the inflammatory process induced by anesthesia and surgery [5-7].

There is no single ideal method of providing anesthesia to this patient group. An optimal approach seems to consist in multimodal anesthesia with short-acting opioids, propofol, an inhaled anesthetic, and a myorelaxant that does not release histamine [8].

\section{Aim}

The aim of the study was to evaluate perioperative complications in patients aged $\geq 75$ years who underwent cardiac surgery in comparison to outcomes in younger patients operated on during the same period.

\section{Material and methods}

We evaluated patients $\geq 75$ years of age who underwent cardiac surgery at the Silesian Centre for Heart Diseases in Zabrze from the implementation of a standard of perioperative care in this age group in October 2009 until October 2014. The study group included 1446 patients. We excluded patients with acute aortic dissection who were subjected to emergency surgery. Patients $\geq 75$ years of age were compared with patients below 75 years of age operated on during the same period (6913 patients).

The risk of renal, respiratory, and cardiac failure $[9,10]$ was evaluated during preoperative anesthesiology consultations.

For premedication, the seniors received melatonin $(5 \mathrm{mg}$ orally) on the evening before the surgery and another dose $1 \mathrm{~h}$ before being transferred to the operating theatre. In the study group, the induction of anesthesia was obtained with intravenous etomidate $(0.2-0.3 \mathrm{mg} / \mathrm{kg})$, sufentanil $50-100 \mu \mathrm{g}$ $(0.5-1 \mu \mathrm{g} / \mathrm{kg})$, and rocuronium (1 mg/kg). In patients with hypotension, ketamine (1-2 mg/kg) was used instead of propofol. Anesthesia was maintained using continuous infusion of propofol (100-200 mg/h) and sufentanil (0.3-1 $\mu \mathrm{g} / \mathrm{kg} / \mathrm{h})$ along with fractionated doses of rocuronium $(0.1 \mathrm{mg} / \mathrm{kg})$. Inhaled sevoflurane was also used at the same time, and was also administered during cardiopulmonary bypass (CPB).

Hemodynamic monitoring included ECG as well as direct blood pressure and central venous pressure measurements. Swan-Ganz catheters were placed in patients with low left ventricular ejection fraction (LVEF < 30\%) or pulmonary hypertension and in patients undergoing complex procedures. We recorded deep body temperature and monitored urine output. We continuously monitored oxygen saturation and frequently measured arterial blood gases with lactate levels during the anesthesia. Mixed venous blood gases were measured if hemodynamic instability occurred. In patients with generalized atherosclerosis, carotid artery stenosis, or a history of stroke, we monitored regional CNS oxygen saturation with near-infrared spectroscopy (NIRS), which is the current standard [11]. An important aspect of management was to maintain normothermia both during the surgery and in the postoperative period. We also established the acceptable level ranges for blood glucose (6.5-8.5 mmol/l) and hemoglobin ( $\geq 5 \mathrm{mmol} / \mathrm{l})$. Fluid balance was strictly monitored, and blood loss was replaced with colloid fluids. We maximally restricted the filling of the CPB circuit. During the initial phase of CPB, the patients received $250 \mathrm{mg}$ of methylprednisolone. During CPB, the mean arterial pressure was kept at $70 \mathrm{~mm} \mathrm{Hg}$, and cardiac output was maintained at $\geq 2.4 \mathrm{l} / \mathrm{m}^{2}$. A lung-sparing ventilation strategy was used (tidal volume $6 \mathrm{ml} / \mathrm{kg}$, positive end-expiratory pressure $\geq 5 \mathrm{~cm} \mathrm{H}_{2} \mathrm{O}, \mathrm{FiO}_{2} 50 \%$ ). Pharmacological and mechanical support of cardiovascular function was provided in accordance with the principles of goaloriented therapy. The goal was defined as a normal lactate level and normal venous blood oxygen saturation, and, in patients monitored using a Swan-Ganz catheter, the goal was to achieve a cardiac index of at least $2.4 \mathrm{l} / \mathrm{m}^{2}$. 
Tab. I. Statistical analysis of intergroup differences in selected parameters: age, body mass index (BMI), risk evaluated using EuroSCORE I, severity of angina according to the Canadian Cardiovascular Society (CCS) classification, severity of heart failure according to the New York Heart Association (NYHA) classification, preoperative left ventricular ejection fraction (LVEF), duration of cardiopulmonary bypass, duration of mechanical ventilation, and duration of hospital stay

\begin{tabular}{lccccc} 
& \multicolumn{3}{c}{$\geq 75$ years } & \multicolumn{3}{c}{$<75$ years } & P-value \\
\cline { 2 - 5 } & Mean & SD & Mean & SD & \\
Age & 78.2 & 3.0 & 61.7 & 9.4 & - \\
\hline BMI & 27.5 & 4.1 & 28.0 & 4.4 & $<0.001$ \\
\hline LVEF & 49.2 & 9.8 & 49.8 & 10.2 & 0.057 \\
\hline EuroSCORE I & 7.66 & 2.39 & 4.28 & 2.60 & $<0.001$ \\
\hline CCS & 2.30 & 1.02 & 2.21 & 1.03 & 0.005 \\
\hline NYHA & 2.08 & 0.86 & 1.78 & 0.95 & $<0.001$ \\
\hline $\begin{array}{l}\text { Duration of cardiopul- } \\
\text { monary bypass }\end{array}$ & 115.7 & 51.4 & 114.3 & 50.1 & 0.493 \\
\hline $\begin{array}{l}\text { Duration of mechanical } \\
\text { ventilation }\end{array}$ & 13.8 & 37.2 & 13.4 & 48.6 & 0.782 \\
\hline $\begin{array}{l}\text { Duration of hospital } \\
\text { stay }\end{array}$ & 9.36 & 6.81 & 8.16 & 7.34 & $<0.001$ \\
\hline
\end{tabular}

SD - standard deviation.

Analgesia was used from admission to the stay in the postoperative unit (morphine in fractionated doses, fixed doses of paracetamol). Antiemetic therapy included dexamethasone and ondansetron. The oxygen level in inspired air was adjusted based on transcutaneous oxygen saturation monitoring. For mechanical ventilation, the SIMV mode was initially used, followed by the bilevel or a proportional mode and, finally, continuous positive airway pressure (CPAP) with pressure support. The intubation tube was removed when the extubation criteria were met. Respiratory rehabilitation and patient mobilization strategies were initiated immediately after extubation. Patients received oral fluids two hours after extubation, and enteral feeding was initiated several hours later. Fluid balance was planned individually.

In younger patients, the approach to anesthesia and early postoperative treatment was decided by the anesthesiologist in charge of anesthesia and the physician on duty in the postoperative unit.

Patients aged $\geq 75$ years were characterized by lower body mass index values, higher risk scores (EuroSCORE I), higher Canadian Cardiovascular Society (CCS) and New York Heart Association (NYHA) classes, and longer durations of hospital stay in comparison to younger patients (Tab. I). Among the seniors, there were more women, patients in NYHA class 3 or 4, patients with an unstable course of ischemic heart disease, left main coronary artery disease, diabetes, hypertension, preoperative renal failure, pulmonary disease, and carotid artery disease (Tab. II).

A comparison of procedures performed in both patient groups is presented in Table III.
Tab. II. Statistical analysis of differences in demographic parameters (gender) and preoperative characteristics - severity of heart failure according to the New York Heart Association (NYHA) classification, severity of ischemic heart disease according to the Canadian Cardiovascular Society (CCS) classification, unstable disease course, left main coronary artery disease, previous myocardial infarction, diabetes, hypercholesterolemia, hypertension, renal dysfunction/failure, chronic pulmonary disease, previous stroke, history of transient ischemic attack (TIA), concomitant carotid artery disease (critical stenoses), and peripheral arterial disease (critical stenoses/occlusion) between seniors and younger patients

\begin{tabular}{|c|c|c|c|c|c|}
\hline \multirow[t]{2}{*}{ Parameter } & \multicolumn{2}{|c|}{$\begin{array}{l}\geq 75 \text { years } \\
(N=1446)\end{array}$} & \multicolumn{2}{|c|}{$\begin{array}{l}<75 \text { years } \\
(N=6909)\end{array}$} & \multirow[t]{2}{*}{$P$-value } \\
\hline & $n$ & $\%$ & $n$ & $\%$ & \\
\hline Female gender & 681 & 47.1 & 2097 & 30.4 & $<0.001$ \\
\hline Male gender & 765 & 52.9 & 4812 & 69.7 & $<0.001$ \\
\hline CCS class 4 & 146 & 10.1 & 633 & 9.2 & 0.288 \\
\hline NYHA class 3 or 4 & 426 & 29.5 & 1390 & 20.1 & $<0.001$ \\
\hline Unstable disease course & 889 & 61.5 & 3773 & 54.6 & $<0.001$ \\
\hline $\begin{array}{l}\text { Left main coronary artery } \\
\text { disease }\end{array}$ & 341 & 23.6 & 1472 & 21.3 & 0.061 \\
\hline Previous Q-wave infarction & 602 & 41.6 & 2780 & 40.2 & 0.341 \\
\hline Diabetes & 507 & 35.1 & 2046 & 29.6 & $<0.001$ \\
\hline Glucose intolerance & 59 & 4.1 & 233 & 3.4 & 0.210 \\
\hline Diabetes (on oral therapy) & 251 & 17.4 & 918 & 13.3 & $<0.001$ \\
\hline Diabetes (on insulin therapy) & 197 & 13.6 & 886 & 12.8 & 0.435 \\
\hline Hypercholesterolemia & 813 & 56.2 & 4110 & 59.5 & 0.024 \\
\hline Hypertension & 1189 & 82.2 & 5323 & 77.0 & $<0.001$ \\
\hline Renal failure & 330 & 22.8 & 704 & 10.2 & $<0.001$ \\
\hline Chronic pulmonary disease & 183 & 12.7 & 571 & 8.3 & $<0.001$ \\
\hline Previous stroke & 85 & 5.9 & 354 & 5.1 & 0.269 \\
\hline History of TIA & 40 & 2.8 & 126 & 1.8 & 0.026 \\
\hline Carotid artery disease & 166 & 11.5 & 530 & 7.7 & $<0.001$ \\
\hline Peripheral arterial disease & 249 & 17.2 & 1163 & 16.8 & 0.750 \\
\hline
\end{tabular}

\section{Statistical analysis}

Data were collected and initially evaluated in a spreadsheet. Verified data were transferred to the statistical software which was used for the proper analysis. Normal distribution of quantitative variables was checked using the Shapiro-Wilk test, while the non-parametric Mann-Whitney $U$ test was used for non-normal variable distribution. For qualitative variables, a two-sided $\chi^{2}$ test with the Yates correction was used. The results are presented in tables showing mean values and standard deviations for quantitative variables and numbers with percentages for qualitative variables. $P<0.05$ was considered statistically significant. Statistical analysis was performed using the Statistica data analysis software system, version 10.1 (StatSoft, Inc.).

\section{Results}

Table IV shows early postoperative complications in both study groups. Mediastinal revision was more common in 
Tab. III. Statistical analysis of intergroup differences with regard to the operations performed (OPCAB - off-pump coronary artery bypass surgery, CABG - coronary artery bypass surgery, TAVI transcatheter aortic valve implantation, complex surgery - valve replacement or repair with concomitant coronary artery bypass surgery, urgent surgery - hospitalization required until the time of the surgery, emergency surgery - surgery required within $24 \mathrm{~h}$ from admission)

\begin{tabular}{lccccc} 
Parameter & $\begin{array}{c}\geq 75 \\
(N=1446)\end{array}$ & \multicolumn{2}{c}{$<75$ years } & P-value \\
\cline { 2 - 5 } & $n$ & $\%$ & $n$ & $\%$ & \\
\cline { 2 - 5 } OPCAB & 666 & 46.1 & 3271 & 47.3 & 0.389 \\
\hline CABG & 148 & 10.2 & 1152 & 16.7 & $<0.001$ \\
\hline Single valve surgery & 291 & 20.1 & 1262 & 18.3 & 0.106 \\
\hline TAVI & 74 & 5.1 & 35 & 0.5 & $<0.001$ \\
\hline $\begin{array}{l}\text { Surgery involving two } \\
\text { or more valves }\end{array}$ & 59 & 4.1 & 377 & 5.5 & 0.038 \\
\hline Complex surgery & 194 & 13.4 & 652 & 9.4 & $<0.001$ \\
\hline $\begin{array}{l}\text { Ascending aortic } \\
\text { aneurysm surgery }\end{array}$ & 14 & 1.0 & 164 & 2.4 & 0.001 \\
\hline Urgent surgery & 847 & 58.6 & 3549 & 51.3 & $<0.001$ \\
\hline Emergency surgery & 62 & 4.3 & 210 & 3.0 & 0.019 \\
\hline $\begin{array}{l}\text { Use of cardiopulmonary } \\
\text { bypass }\end{array}$ & 706 & 48.8 & 3607 & 52.2 & 0.021 \\
\hline
\end{tabular}

older patients, as was low cardiac output syndrome requiring high catecholamine doses and mechanical support with an intra-aortic balloon. Other complications were also more frequently diagnosed in older patients, including pulmonary complications, acute renal failure (defined as serum creatinine level $\geq 200 \mu \mathrm{mol} / \mathrm{l}$ ), type I neurological complications, and abdominal organ dysfunction (intestinal ischemia/necrosis, acute cholecystitis, acute pancreatitis, gastrointestinal bleeding). Atrial fibrillation and delirium were more common in older patients. Transfusion of more than 4 units of packed red blood cells was also more frequent in this group. The overall complication rate was higher in older patients (17.8\%), and in-hospital mortality in this group was 3.8\%.

The rate of prolonged mechanical ventilation, defined as patient dependence on the ventilator lasting more than $48 \mathrm{~h}$, was the same in both groups (Tab. V). Gender and preoperative factors had no effect on the duration of mechanical ventilation (Tab. VI).

The mean duration of mechanical ventilation in our patients $\geq 75$ years of age was shorter by more than $10 \mathrm{~h}$ compared to the mean value in a similar group of patients analyzed in 2003-2008 (Tab. VII).

The rate of postoperative delirium in patients $\geq 75$ years of age operated on due to cardiac disease in 2003-2008 was $15.7 \%$, i.e., nearly twice as high as in the present study group (Tab. VII).

\section{Discussion}

The implementation of the Early Recovery After Surgery (ERAS) approach, used in general surgical, orthopedic, and
Tab. IV. Statistical analysis of intergroup differences with regard to postoperative complications (reoperation - a surgical revision of the mediastinum required due to excessive drainage, cardiac tamponade, graft or valve dysfunction, or exploratory surgery due to unexplained cardiovascular decompensation; low cardiac output syndrome defined as the need to use two catecholamines in doses above $10 \mu \mathrm{g} / \mathrm{kg} / \mathrm{min}$ each or epinephrine in a dose above $0.1 \mathrm{\mu g} / \mathrm{kg} / \mathrm{min}$ or as a cardiac index below $2 \mathrm{l} / \mathrm{min} / \mathrm{m}^{2}$ in two consecutive measurements; IABP - intra-aortic balloon counterpulsation, perioperative infarction - documented by ECG and biochemical testing, AF - atrial fibrillation; pulmonary complications - postoperative occurrence of pneumothorax, hemopericardium requiring drainage, pneumonia, pulmonary edema, ARDS, or hypodynamic respiratory failure; delirium - sudden change of mental status, impaired consciousness or attention, chaotic thinking; type I neurological complications - ischemic or hemorrhagic stroke, TIA, coma, anoxic encephalopathy; renal failure - serum creatinine level above $200 \mu \mathrm{mol} / \mathrm{l}$ or the need for renal replacement therapy; abdominal organ dysfunction - intestinal ischemia/necrosis, acute cholecystitis, acute pancreatitis, gastrointestinal bleeding)

\begin{tabular}{|c|c|c|c|c|c|}
\hline \multirow[t]{2}{*}{ Parameter } & \multicolumn{2}{|c|}{$\begin{array}{l}\geq 75 \text { years } \\
(N=1446)\end{array}$} & \multicolumn{2}{|c|}{$\begin{array}{l}<75 \text { years } \\
(N=6909) \\
\end{array}$} & \multirow[t]{2}{*}{$P$-value } \\
\hline & $n$ & $\%$ & $n$ & $\%$ & \\
\hline Mechanical ventilation $>48 \mathrm{~h}$ & 40 & 2.8 & 154 & 2.2 & 0.254 \\
\hline Reoperation & 137 & 9.5 & 518 & 7.5 & 0.013 \\
\hline $\begin{array}{l}\text { Excessive mediastinal } \\
\text { drainage }\end{array}$ & 76 & 5.3 & 295 & 4.3 & 0.113 \\
\hline Cardiac tamponade & 26 & 1.8 & 110 & 1.6 & 0.654 \\
\hline Low cardiac output syndrome & 579 & 40.0 & 1932 & 28.0 & $<0.001$ \\
\hline $\begin{array}{l}\text { Epinephrine dose } \\
>0.1 \mu \mathrm{g} / \mathrm{kg} / \mathrm{min}\end{array}$ & 85 & 5.9 & 264 & 3.8 & $<0.001$ \\
\hline IABP & 72 & 5.0 & 229 & 3.3 & 0.003 \\
\hline Perioperative infarction & 12 & 0.8 & 53 & 0.8 & 0.934 \\
\hline $\mathrm{AF}$ & 424 & 29.3 & 1306 & 18.9 & $<0.001$ \\
\hline Pulmonary complications & 28 & 1.9 & 90 & 1.3 & 0.083 \\
\hline Delirium & 116 & 8.0 & 240 & 3.5 & $<0.001$ \\
\hline $\begin{array}{l}\text { Type I neurological } \\
\text { complications }\end{array}$ & 49 & 3.4 & 112 & 1.6 & $<0.001$ \\
\hline Renal failure & 133 & 9.2 & 317 & 4.6 & $<0.001$ \\
\hline Abdominal organ dysfunction & 36 & 2.5 & 64 & 0.9 & $<0.001$ \\
\hline $\begin{array}{l}\text { Transfusion of > } 4 \text { units } \\
\text { of packed red blood cells }\end{array}$ & 326 & 22.5 & 906 & 13.1 & $<0.001$ \\
\hline Complications overall & 257 & 17.8 & 744 & 10.8 & $<0.001$ \\
\hline Postoperative unit mortality & 38 & 2.6 & 76 & 1.1 & $<0.001$ \\
\hline In-hospital mortality & 55 & 3.8 & 106 & 1.5 & $<0.001$ \\
\hline
\end{tabular}

other surgical units, has introduced some unrest into the monotonous standard of perioperative care in patients undergoing cardiac surgery. The idea was born and developed in Scandinavia, from where it later emanated to other parts of the world [12]. It seems that this philosophy of perioperative care may have an effect on the reduction of complication rates in all areas of surgery. This is even more likely due to the current trend to operate on older and older patients who tend to stay for a longer time in the postoperative 
Tab. V. The effect of preoperative parameters - age, body mass index (BMI), left ventricular ejection fraction (LVEF), risk evaluated using EuroSCORE I, severity of angina according to the Canadian Cardiovascular Society (CCS) classification, severity of heart failure according to the New York Heart Association (NYHA) classification) and duration of cardiopulmonary bypass on the need of prolonged ( $>48 \mathrm{~h}$ ) postoperative mechanical ventilation in patients $\geq 75$ years of age

\begin{tabular}{lccccc}
\hline \multirow{2}{*}{ Parameter } & \multicolumn{5}{c}{ Mechanical ventilation > 48 h } \\
\cline { 2 - 5 } & \multicolumn{3}{c}{ No } & \multicolumn{3}{c}{ Yes } & P-value \\
\cline { 2 - 5 } Age & Mean & SD & Mean & SD \\
\hline BMI & 78.2 & 3.0 & 78.7 & 2.5 & 0.353 \\
\hline LVEF & 27.5 & 4.1 & 26.5 & 4.0 & 0.110 \\
\hline EuroSCORE I & 49.3 & 9.7 & 46.0 & 11.5 & 0.046 \\
\hline CCS & 7.62 & 2.36 & 9.03 & 3.19 & $<0.001$ \\
\hline NYHA & 2.30 & 1.01 & 2.14 & 1.22 & 0.341 \\
\hline $\begin{array}{l}\text { Duration of cardiopul- } \\
\text { monary bypass }\end{array}$ & 2.07 & 0.86 & 2.35 & 0.68 & 0.053 \\
\hline
\end{tabular}

SD - standard deviation.

unit, which results in postoperative delirium and increased severity of dementia, ultimately annihilating much of the initial effect of the surgery.

Years ago, some emotions in cardiac surgery were generated by the fast-track standard, but ultimately it focused on early extubation in low-risk patients.

The aging of society is a problem in developed and developing countries [13]. Patients referred for cardiac surgery also tend to be increasingly old. Frailty is a feature of the multidimensional syndrome associated with aging, characterized by a loss of physiological reserve and deficit accumulation [14]. As a result, these patients are helpless when trauma occurs.

In the present study, patients aged 75 years and above constituted $21 \%$ of the overall population undergoing surgery. For premedication, we used melatonin, which, according to various authors, restores the normal sleep and wake cycle, thus contributing to a reduction in the rate of delirium. This therapy was continued in the early postoperative period [15]. We avoided benzodiazepine use throughout the perioperative period. Statin treatment was not discontinued before the surgery, and statins were initiated in patients who had not previously received these drugs [16].

Short-acting drugs were used for multimodal, intravenous, and inhaled anesthesia. We also used sevoflurane, which is well known for its preconditioning properties.

Hemodynamic monitoring was performed according to the accepted standard, which was not modified in the evaluated age group. In the case of low cardiac output syndrome after the surgery, monitoring was supplemented with cardiac output measurements using the thermodilution method. Venous blood oxygen saturation and the lactate level were measured in order to enable early detection of impending hemodynamic destabilization. When treating
Tab. VI. The effect of preoperative parameters (gender, New York Heart Association (NYHA) class 3 or 4 of heart failure, severe ischemic heart disease (Canadian Cardiovascular Society (CCS) class 4), unstable disease course, left main coronary artery disease, previous myocardial infarction, diabetes, hypercholesterolemia, hypertension, renal dysfunction/failure, chronic pulmonary disease, previous stroke, history of transient ischemic attack (TIA), concomitant carotid artery disease (critical stenoses), and peripheral artery disease (critical stenoses/occlusion)) on the need of prolonged ( $>48 \mathrm{~h}$ ) postoperative mechanical ventilation in patients $\geq 75$ years of age

\begin{tabular}{|c|c|c|c|c|c|}
\hline \multirow[t]{4}{*}{ Parameter } & \multicolumn{5}{|c|}{ Mechanical ventilation $>48 \mathrm{~h}$} \\
\hline & \multirow{2}{*}{\multicolumn{2}{|c|}{$\begin{array}{c}\text { No } \\
(N=1406)\end{array}$}} & \multirow{2}{*}{\multicolumn{2}{|c|}{$\begin{array}{c}\text { Yes } \\
(N=40)\end{array}$}} & \multirow[t]{3}{*}{$P$-value } \\
\hline & & & & & \\
\hline & $n$ & $\%$ & $n$ & $\%$ & \\
\hline Female gender & 657 & 46.7 & 24 & 60.0 & 0.134 \\
\hline Male gender & 749 & 53.3 & 16 & 40.0 & 0.134 \\
\hline CCS class 4 & 140 & 10.0 & 6 & 15.0 & 0.437 \\
\hline NYHA class 3 or 4 & 409 & 29.1 & 17 & 42.5 & 0.097 \\
\hline Unstable disease course & 862 & 61.3 & 27 & 67.5 & 0.530 \\
\hline $\begin{array}{l}\text { Left main coronary artery } \\
\text { disease }\end{array}$ & 331 & 23.5 & 10 & 25.0 & 0.980 \\
\hline Previous Q-wave infarction & 589 & 41.9 & 13 & 32.5 & 0.305 \\
\hline Diabetes & 497 & 35.4 & 10 & 25.0 & 0.236 \\
\hline Glucose intolerance & 59 & 4.2 & 0 & 0.0 & 0.359 \\
\hline Diabetes (on oral therapy) & 249 & 17.7 & 2 & 5.0 & 0.060 \\
\hline Diabetes (on insulin therapy) & 189 & 13.4 & 8 & 20.0 & 0.338 \\
\hline Hypercholesterolemia & 796 & 56.6 & 17 & 42.5 & 0.107 \\
\hline Hypertension & 1155 & 82.2 & 34 & 85.0 & 0.798 \\
\hline Renal failure & 320 & 22.8 & 10 & 25.0 & 0.887 \\
\hline Chronic pulmonary disease & 180 & 12.8 & 3 & 7.5 & 0.451 \\
\hline Previous stroke & 83 & 5.9 & 2 & 5.0 & 0.919 \\
\hline History of TIA & 39 & 2.8 & 1 & 2.5 & 0.700 \\
\hline Carotid artery disease & 162 & 11.5 & 4 & 10.0 & 0.963 \\
\hline Peripheral arterial disease & 238 & 16.9 & 11 & 27.5 & 0.125 \\
\hline
\end{tabular}

Tab. VII. The duration of postoperative mechanical ventilation and the rate of postoperative delirium in patients $\geq 75$ years of age who underwent cardiac surgery at the Silesian Centre for Heart Disease in Zabrze in the years 2003-2008

\begin{tabular}{lccc} 
Duration of mechanical ventilation & $(\geq 75$ years) & \\
\hline Period [years] & $N$ & Mean & $S D$ \\
2003-2008 & 593 & 24.2 & 55.3 \\
Delirium ( $\geq 75$ years) & & & \\
\hline Period [years] & \multicolumn{3}{c}{} \\
2003-2008 & 96 & 15.96 \\
\hline
\end{tabular}

SD - standard deviation.

heart failure, we were fully aware of a high likelihood of concomitant left ventricular diastolic dysfunction, which is characteristic for the evaluated age group. The treatment of choice for this type of heart failure is the administration 
of milrinone combined with norepinephrine. Fluid therapy in patients with diastolic heart failure is a real challenge. Adequate cardiac filling requires higher pressures, but the stiff myocardium is characterized by low end-diastolic volume. Low cardiac output syndrome is defined as the need to use two catecholamines in doses above $10 \mu \mathrm{g} / \mathrm{kg} / \mathrm{min}$ each or epinephrine in a dose above $0.1 \mu \mathrm{g} / \mathrm{kg} / \mathrm{min}$ or as a cardiac index below $2 \mathrm{l} / \mathrm{min} / \mathrm{m}^{2}$ in two consecutive measurements. Such a condition was observed in $40 \%$ of the seniors undergoing surgery. Mechanical cardiac support was used in $5 \%$ of patients aged 75 years and above.

Modern sedation facilitates patient cooperation with the medical personnel, as it provides comfort, while allowing patients to communicate their needs. In order to achieve this condition, effective analgesia should be provided, nausea and vomiting should be avoided, and the ventilator's operation should be synchronized with the patient's spontaneous breathing. All patients who required deeper sedation and were ventilated for more than $24 \mathrm{~h}$ were evaluated daily to determine their readiness to be weaned from mechanical ventilation [17]. Despite many concomitant conditions and risks present in our seniors, the duration of postoperative mechanical ventilation did not differ between the groups. The only modifiable factor that affects the duration of postoperative mechanical ventilation is cardiopulmonary bypass, particularly its duration. Our results are consistent with often presented data indicating benefits of avoiding CPB in high-risk patients [18]. When evaluating the duration of mechanical ventilation in two different periods (2003-2008 versus 2009-2014), one should take into account the advances in surgical techniques, the increasing surgeon experience, and the introduction of protective mechanical ventilation. It seems, however, that the observed significant reduction in the duration of mechanical ventilation is also associated with the implementation of a standard of perioperative care for seniors.

Acute renal failure was treated in accordance with the standard approach introduced many years ago [19]. For more than 5 years, renal replacement therapy in the early postoperative period has been conducted under local anticoagulation using citrate [20].

An issue of ongoing debate in the medical literature is the optimal hemoglobin level during the perioperative period in elderly patients. On the one hand, every transfused unit of packed red blood cells is associated with an increase in mortality risk; on the other hand, anemia can cause acute postoperative renal failure, strokes, and respiratory failure [21]. In our study, indications for packed red blood cell transfusions were individualized, taking into account factors other than the hemoglobin level. The need for transfusion was considered in the context of the lactate level, venous blood oxygen saturation, and, in the perioperative period, also patient participation in rehabilitation. Despite the restrictive indications for transfusion, the need to use more than 4 units of packed red blood cells occurred in $22.55 \%$ of seniors and was significantly more frequent than in the case of younger patients.
Early postoperative delirium is associated with an increased risk of complications, prolonged duration of hospital stay, and increased mortality [22]. In our seniors, delirium was more than twice as frequent as in our younger patients. However, we were able to reduce the rate of delirium in comparison to the period before the implementation of the standard of perioperative care in seniors in 2009. In 2003-2008, postoperative delirium was observed in $15.7 \%$ of patients aged $\geq 75$ years, as compared to $8 \%$ of patients at a similar age in the present study group.

\section{Conclusions}

Patients aged $\geq 75$ years who undergo cardiac surgery have significantly more concomitant conditions involving other organs, which affects treatment outcomes (duration of hospital stay, mortality). The implementation of a standard of perioperative care in this age group reduced the duration of mechanical ventilation and lowered the rate of postoperative delirium.

\section{Disclosure}

Authors report no conflict of interest.

\section{References}

1. Vymazal T. Fast-track is more than physiological anaesthsia. Heart Lung Vessel 2014; 6: 77-78.

2. Makary M, Segev DL, Pronovost PJ, Syin D, Bandeen-Roche K, Patel P, Takenaga R, Devgan L, Holzmueller CG, Tian J, Fried LP. Fraility as a predictor of surgical outcomes in older patients. J Am Coll Surg 2010; 210: 901-908.

3. Sophie S. Anaesthesia for the elderly patients. J Pac Med Assoc 2007; 57: 196-201.

4. Levine WC, Mehta V, Landesberg G. Anesthesia for the elderly: selected topics. Curr Opin Anaesth 2006; 19: 320-324.

5. Strom C, Rasmussen LS, Sieber FE. Should general anaesthesia be avoided in the elderly? Anesthesia 2014; 69 (Suppl): 35-44.

6. Krenk L, Rasmussen L, Kehlet H. Delirium in the fast-track surgery setting. Best Pract Res Clin Anaesthesiol 2012; 26: 345-353.

7. Silbert B, Evered L, Scott DA. Cognitive decline in elderly: is anaesthesia implicated? Best Pract Res Clin Anaesthesiol 2011; 25: 379-393.

8. Mandel JE. Consideration for the use of short-acting opioids in general anes thesia. J Clin Anesth 2014; 26 (1 Suppl): S1-S7.

9. Knapik P, Rozentryt P, Nadziakiewicz P, Polonski L, Zembala M. Retrospective cross-validation of simplified predictive index for renal replacement therapy after cardiac surgery. Interact Cardiovasc Thorac Surg 2008; 7: 1101-1106.

10. Knapik P, Cieśla D, Wawrzyńczyk M, Knapik M, Borkowski J, Zembala $M$. Incidence and prediction of permanent neurological deficits after cardiac surgery - are the existing models of prediction truly global? Eur J Cardiothorac Surg 2010; 37: 717-723.

11. Kucewicz-Czech E, Urbańska E, Knapik P, Borkowski J, Podwińska E. Monitorowanie regionalnej saturacji mózgowej podczas zabiegów kardiochirurgicznych - algorytm postępowania. Kardiochir Torakochir Pol 2011; 8: 504-508.

12. http://eras.org.in/eras-protocol/

13. Slany $E$, Abel $M$, Reuter W. Geriatric surgery or geriatrisation of surgical medicine. Versicherungsmedizin 2011; 63: 3-10.

14. Partridge JS, Harari D, Dhesi JK. Frailty in the older surgical patient: a review. Age Ageing 2012; 41: 142-147.

15. Bourne RS, Mills GH, Minelli C. Melatonin therapy to improve nocturnal sleep in critically ill patients: encouraging result from a small randomized controlled trial. Crit Care 2008; 12: R52.

16. Liakopoulos OJ, Choi YH, Haldenwang PL, Strauch J, Wittwer T, Dörge H, Stamm C, Wassmer G, Wahlers T. Impact of preoperative statin therapy on adverse postoperative outcomes in patients undergoing cardiac surgery: a meta-analysis of over 30000 patients. Eur Heart J 2008; 29: 1548-1559. 
17. Kress JP, Pohlman AS, O’Connor MF, Hall JB. Daily interruption of sedative infusions in critically ill patients undergoing mechanical ventilation. $\mathrm{N}$ Engl J Med 2000; 342: 1471-1477.

18. Ji Q, Mei Y, Wang X, Ding W. On-pump versus off-pump coronary artery bypass surgery in high-risk patients. Int Heart J 2014; 55: 484-488.

19. Kucewicz-Czech E, Oliwa M, Puzio J, Knapik P, Włoczka G, Szary T, Czech B, Wojarski J, Borzymowski J. Ostra niewydolność nerek wymagająca terapii nerkozastępczej jako powikłanie operacji serca. Wiad Lek 2007; 1-2: 10-14.

20. Kucewicz E, Żegleń S, Wojarski J, Ochman M, Skuza K, Szczepańska A, Podwińska E, Pacholewicz J, Przybylski R. Ostra pooperacyjna niewydolność nerek leczona hemodiafiltracją z wykorzystaniem regionalnej antykoagulacji. Anest Inten Ter 2009; 41: 238-241.

21. Carson JL, Terrin ML, Noveck H, Sanders DW, Chaitman BR, Rhoads GG, Nemo G, Dragert K, Beaupre L, Hildebrand K, Macaulay W, Lewis C, Cook DR, Dobbin G, Zakriya KJ, Apple FS, Horney RA, Magaziner J; FOCUS Investigators. Liberal or restrictive transfusion in high-risk patients after hip surgery. N Engl J Med 2011; 365: 2453-2462.

22. Krzych ŁJ, Święch W, Białek K, Krysta K, Krupka-Matuszczyk I, Bochenek A. Delirium in cardiac surgery patients - a multi-disciplinary approach. Kardiol Pol 2011; 69: 479-481. 